\title{
AYOKEDEA AND UMKMGOOL WEBSITE: ACCELERATION SOLUTIONS DEVELOPMENT OF SMES AND COMMUNITIES IN THE VILLAGE
}

\author{
Jajat Sudrajat, Meiryani, Nugroho Juli Setiadi \\ Bina Nusantara University, Indonesia \\ jsudrajat@binus.edu
}

\begin{abstract}
The Tridharma Perguruan Tinggi program through the collaboration of lecturers from various departments and students in the Community Service Program, through the media information website Ayokedesa The purpose of the long-term Community Service Program implementation in this program is to produce a partnership model. This strategy is carried out to build partnerships with related parties that can increase success in the Small and Medium Enterprises sector as well as communities in the Campakamulya and Pasirmulya Banjaran Villages of Bandung and the Thousand Islands of DKI Jakarta, by implementing strategies through online marketing of products through the UMKMGool website. This Online Marketing Partnership application aims to accelerate business development in the village so as to increase sales. The method to be used is the fact finding method, in addition to collecting data in the literature, also conducting interviews with MSMEs and the community and business process surveys to collect supporting data. The output of this service is the Online Marketing Partnership Application in the form of the UMKMGool website and the ayokedesa information media website, as a means of business idea media, entrepreneurial spirit, business concepts. In addition, through the development of the ayokedesa website, optimizing the implementation of higher education Tridharma namely Teaching, Research and Community Service can help accelerate the development of prosperous villages.
\end{abstract}

Keywords: Community And Community Development, Online Marketing, Community, Prosperous Village

\section{INTRODUCTION}

Ayokedesa and UMKMGool website, is a solution to accelerate the development of MSMEs and Communities in the villages of Campakamulya and Pasirmulya, Banjaran District, Bandung and the Thousand Islands. The three villages have been fostered by Binus University since 2018. In 2019, besides developing the Ayokedesa website content and the UMKMGool Prototype website, this website is a solution for the development of MSMEs and Community in the Village, as one of the solutions to the wishes and hopes of President Jokowi, he hope the younger generation can use social media wisely. Internet technology and social media, if used positively, have many benefits, but on the other hand, this technology also has a negative impact.

Our community service program in 2019 with Binus University Community Development Academic (CDA), namely on 18-19 July 2019 on Pramuka Island and Panggang Island, Thousand Islands, DKI Jakarta Province, and 7 - 8 August 2019 in Pasirmulya Village and Campaka Mulya Village, Bandung Regency. Based on our observations of MSMEs and the Community, most of them already have products and have been selling their products for several years, so we are trying to provide solutions to increase sales. Some lecturers from various majors who came with us were lecturers majoring in Hotel Management, majoring in Information Systems, majoring in accounting, majoring in marketing communication. They share their knowledge according to their competence. Hotel Management Department provides training on making shredded fish, accounting department provides training on how to calculate production costs, Information Systems department provides training on website utilization and optimizes Instagram social media for product promotion, management department provides training for making labels and optimizes social media and socializes ayokedesa website and UMKMGool as a promotion and marketplace media. 
MSMEs and communities in the village are now using smartphones a lot for their daily activities, they are accustomed to opening whatsapp, instagram, facebook and other social media. Based on this, we point their smartphones to be optimized for business development and other information such as socialization for preparedness and sustainable mitigation in the face of natural disasters, they are enthusiastic and understand their smartphone functions to be more useful and optimal utilization. The learning process can be enjoyed by MSMEs and the Community in the Village independently. The results of the study understand that combining various theories and learning approaches to promote entrepreneurial awareness and mindset. Entrepreneurship education is also needed to be student-centered and focus on life experiences and learning practices, so that various learning theories can be combined with practical experiences (San Tan \& Ng, 2006)

Collaboration between lecturers and students in community service programs will be optimally implemented to help develop MSMEs and Communities in villages throughout the archipelago, so that higher education institutions should consider producing graduates as entrepreneurs. Entrepreneurship education in universities must be fully reviewed and changed. Clear goals must be set for developing entrepreneur-oriented graduates, so the education process will require a lot of restructuring to improve the development of entrepreneurial skills (Taatila, 2010). Becoming an Entrepreneur is difficult, it needs to prepare physically and mentally and spiritually, however an entrepreneur can be a hero to others because many people even Thousands of families get jobs (Sudrajat, 2016), we continue to motivate the young generation in the village and students to rebuild the village with the slogan Ayokedesa.

\section{PARTNER PROFILE ANALYSIS}

Based on observations we made on July 18-19, 2019 on Pramuka Island and Pulau Seribu Thousand Islands, the potential of MSME and Community products is in the form of fish cracker products, so that the MSME and dam community development programs develop shredded fish products. On August 8-9 in Pasirmulya Village and Campakamulya Village, Bandung Regency, the potential for the development of the Leading Rural Products namely Coffee, one of which is UMKM Kopi, has now expanded its business by creating a new brand name "Intina Kopi Cafe", originally the brand "Habenagen". In addition to MSMEs and the Community, we visited coffee farmers, whose name is Mr. Ayi Sutedja(Amalia \& others, 2018), one of the main Coffee Farmers from Mount Puntang who won a coffee competition in Toronto Canada.

\section{PARTNER ISSUES}

At present the fundamental problems experienced by MSMEs and Communities in the villages of Pasirmulya and Campakamulya and Pramuka Island and Panggang Island in the Thousand Islands are product marketing and branding.

\section{SOLUTIONS}

Ayokedesa and UMKMGool website, is one of the solutions to accelerate the problem of MSMEs and Communities, this website media continues to be developed both in content and business processes, making it easier for MSMEs and Communities to use it. Smartphone and human resources, especially the younger generation in the village, namely the "Karang Taruna" community, are communities that continue to be fostered as a medium of contact between educational institutions and the community in the village. this can be done with the support of technology media so that the delivery of information is faster and more accurate, information 
management requires good technology, because information is a very important one for a company or institution. Our next solution will be to work periodically with government officials through the optimization of rural development programs, so that the village-owned enterprises (BUMDes) will be more beneficial and accelerate the development of prosperous villages.

UMKM and the community can independently learn for business development, so they will be motivated and inspired to continue to open the ayokedesa website as an alternative information on the development of entrepreneurship education or training. So that there will be a synergy of collaboration between MSMEs and the Community with lecturers and students who will help with business development, because students have already had entrepreneurship courses. The positive effect of entrepreneurship education on graduates' future plans to start a business is made possible through independent selection so that the quality of educational content is entrepreneurial in terms of academic and teaching content and learning methods require further attention. It would make more sense for some students to take entrepreneurship education comprehensively(San Tan \& Ng, 2006).

Based on the description above, the ayokedesa website and the UMKMGool website can provide alternative solutions for problem solving, to overcome marketing problems by utilizing internet media technology with one of the dynamic websites used to reach a wider market so that it is expected to increase sales turnover from the UMKM. . After MSME and the community develops, we will provide training in bookkeeping / accounting management, because whatever form of business and the amount of capital owned, making financial reports or bookkeeping is a must. With bookkeeping, every business activity will be recorded properly which can be used as a barometer and indicator to determine the company's performance that is being implemented to support a more productive, efficient and effective financial process that can increase profit or profit (Rudiantoro \& Siregar, 2012). After attending the training, it is expected that MSMEs can develop business management skills. Business skills can be learned through the Canvas Business Model so students and MSMEs can collaborate because they already have managerial competencies to develop relationships between entrepreneurial managerial competencies such as administration, knowledge and technology competencies, network building competencies, communication skills, business and financial development models (Zarefard \& Cho, 2018). 
AYO KE DESA

BiNus Bangun Desa

IULI 22, 2019 OLEH AYOKFDFS

PELUANG \& TANTANGAN UMKM

Carl..

Q

KEPULAUAN 1000

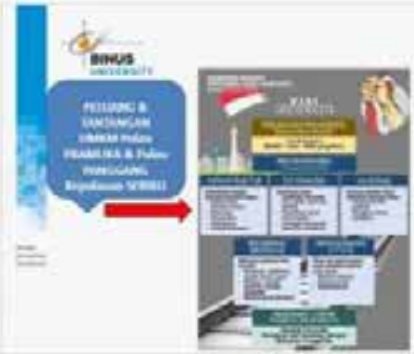

POS.POS TERBARU

Website UMKM

HARAPAN ORANG TUA KEPADA ANAK

Research Ethic \& Reference Tool using Mendelcy

Model Pelatihan Menyenarughan (FUN)

PELUANG \& TANTANGAN UMKM KEPULAUAN 1000

Figure 1. Website Development ayokedesa.com

Source: Jajat Sudrajat, 2019

Based on the picture 1. MSMEs and Communities will get information on business opportunities and challenges in various villages throughout Indonesia so that they will be motivated to work together.

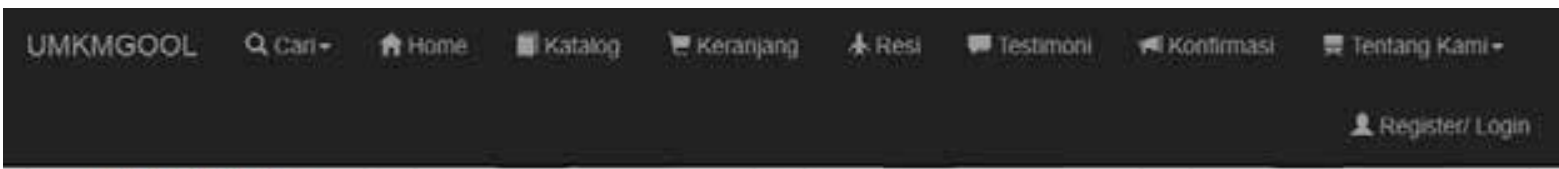

\section{Rp 2.050.000.-}
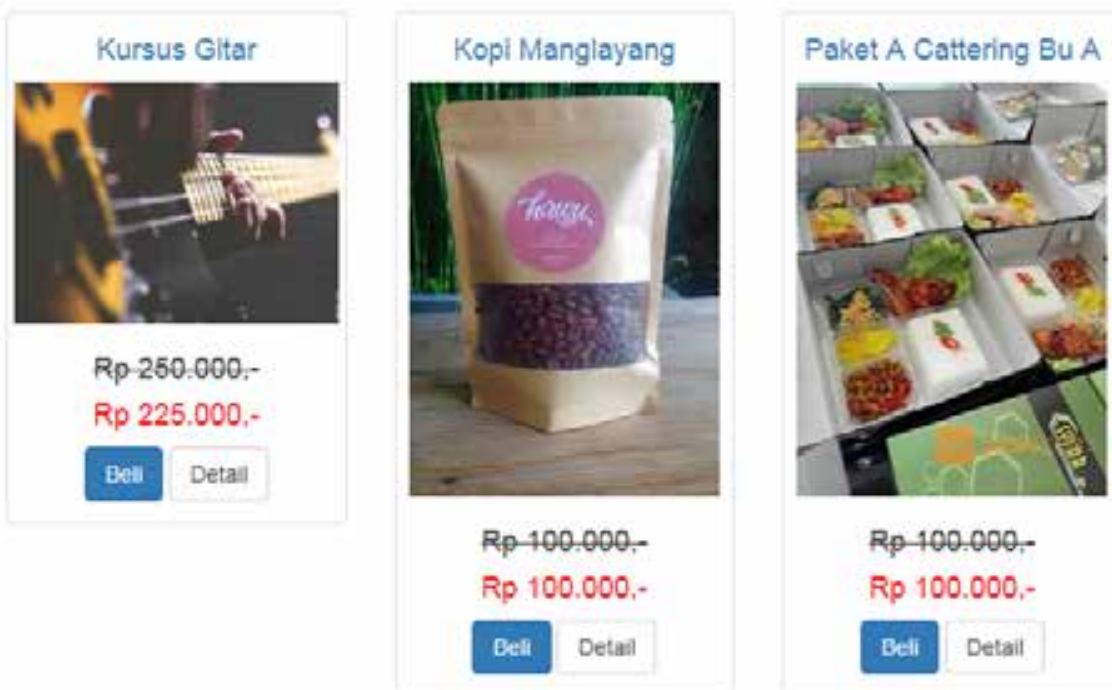

Rp-100.000-

Rp 100.000.-

Detail 
Figure 2. Prototype of UMKMGool.com Website

Source: Jajat Sudrajat, 2019

Based on picture 2, namely the UMKMGool website is a solution for developing UMKM and the Community in developing the sale of its products through the UMKMGool website, so that they can collaborate with MSMEs in other villages in developing their products and marketing.

\section{IMPLEMENTATION METHOD}

Based on observations that have been made during 5 visits, generally MSMEs and Communities in the village are the main problems in the field of marketing, media promotion and marketing tools that are commonly done namely websites, now available, but not yet focused on the marketing field, but several MSMEs and Communities has used Smartphones as a marketing communication medium. To overcome marketing problems, one solution is to use the UMKMGool Website for MSMEs and novice communities, but for those who are already running their business and want to develop their marketing, they can use marketplaces such as Tokopedia, Blibi, Bukalapak and other marketplaces. In making this application it will optimize the Smartphone device as a marketing tool. In implementing the application, we will use the implementation method by involving or collaborating with other MSME partners and communities.

\section{CONCLUSION}

In overcoming the problems of MSMEs and the Community, where one of the problems is marketing, the conclusions to overcome the problem are as follows:

1. To socialize ayokedesa website, so that their activities can be published as product branding.

2. Socializing the UMKMGool website as a media product promotion and can increase sales of its products.

3. Improving business management, one of which is tidying up the recording of purchases and sales, to measure and evaluate sales or revenue progress regularly.

\section{REFRENCE.}

Amalia, W. G., \& others. (2018). Analisis Faktor-Faktor Yang Mempengaruhi Cita Rasa Kopi Puntang di Desa Cimaung Kabupaten Bandung”. Perpustakaan Fakultas Ekonomi dan Bisnis Unpas Bandung.

San Tan, S., \& Ng, C. K. F. (2006). A problem-based learning approach to entrepreneurship education. Education+ Training, 48(6), 416-428.

Sudrajat, J. (2016). Memahami Belajar Entrepreneurship di Perguruan Tinggi. Deepublish.

Taatila, V. P. (2010). Learning entrepreneurship in higher education. Education+ Training, 52(1), 48-61.

Zarefard, M., \& Cho, S. E. (2018). ENTREPRENEURS'MANAGERIAL COMPETENCIES AND INNOVATIVE START-UP INTENTIONS IN UNIVERSITY STUDENTS: FOCUS ON MEDIATING

FACTORS. International Journal of Entrepreneurship, 22(2), 1-22. 